\title{
COMMENTARY
}

\section{The food crisis isn't over}

\section{Although the credit crunch has lowered the price of food, a global recession now raises the hunger pains of the most vulnerable. The stage is set for the next international food crisis, says Joachim von Braun.}

$$
J^{0}
$$
ust a few months ago, the 'crisis' on everyone's mind was the spike in food prices. Then the financial crisis gripped the world, food prices declined somewhat, and agricultural concerns lost their sense of immediacy. But we should not be complacent. The credit crunch is likely to have

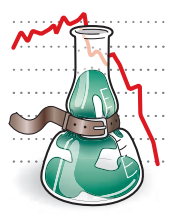

RECESSION WATCH
Agricultural R\&D is one of the most effective types of investment for preventing food crises, promoting economic growth and reducing poverty ${ }^{3}$. Global underinvestment has impaired productivity in recent years. As growth of public agricultural $\mathrm{R} \& \mathrm{D}$ spending in low- and middle-income countries decreased from $3 \%$ in the 1980 s to $1.9 \%$ in the 1990s (ref. 4), global grain productivity growth declined from about $3 \%$ to $1 \%$ (ref. 5 ).

Doubling all agricultural R\&D in developing countries between 2008 and 2013, from US\$5 billion to $\$ 10$ billion, could increase agricultural growth by 1.1 percentage points a year, and lift about 282 million people out of poverty to compensate for their shrinking purchasing power. From 2003-05 to 2007, the number of undernourished people increased from some 848 million to 923 million, largely because of the food-price crisis ${ }^{1}$.

The worldwide credit crunch has let some air out of the commodity price bubble, providing a little relief - cereal prices have fallen by about $30-40 \%$ in recent months. But recession also threatens to cut the income and employment of the most vulnerable and undermine investment in agricultural production. The economic bailout and suggested market regulations now being discussed will not protect food prices from future spikes. The world's food worries are by no means over.

\section{The path to malnourishment}

An International Food Policy Research Institute (IFPRI) model, developed by division director Mark Rosegrant, explores what might happen in the face of the recession. If global economic annual growth falls by 2-3 percentage points below recent years' figure of about $5 \%$, and agricultural investment declines in parallel by $20 \%$ - a realistic scenario - this would result in cereal prices $30 \%$ above what is expected without a recession by 2020 (ref. 2). Globally, 16 million more children would be malnourished.

However, if spending on agricultural research and development (R\&D) is maintained (assuming a modest $3 \%$ decline in investment growth) in the face of this recession, cereal prices would be about $15 \%$ lower than the non-recession baseline in 2020, and malnutrition would be about the same as in the baseline scenario (see graph).

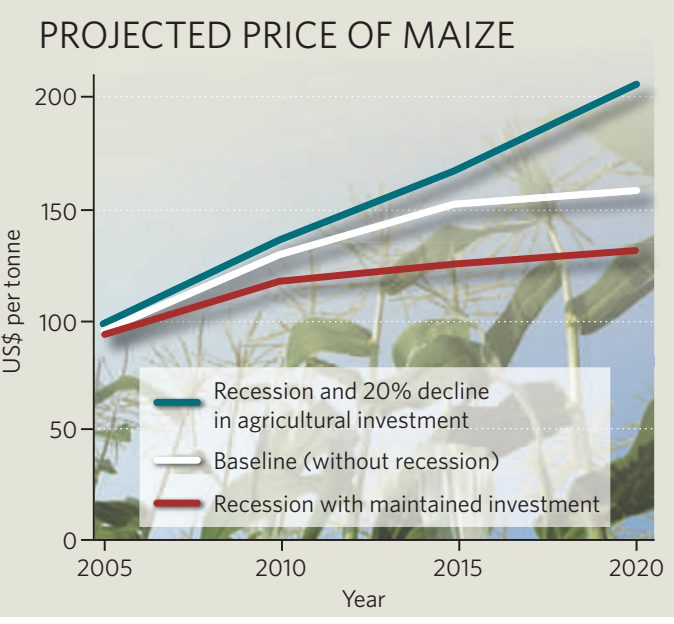

by 2020 (ref. 2). Although this would mark a historic turnaround in such investment, it pales in comparison to the financial bailout costs.

Much investment will have to be facilitated by public sources, in view of the deepening shortage of private capital and the risky investment climate. Institutions such as the World Bank and the Asian Development Bank have recently reversed their declining investments in agriculture, with substantial increases seen in 2007 and 2008. Such trends need to continue.

Investment in $\mathrm{R} \& \mathrm{D}$ is necessary to keep long-term food prices at reasonable levels. But to avoid price bubbles, action needs to be taken to improve market efficiency and food trade in crisis situations. The IFPRI recommends an emergency reserve of 300,000 tonnes of grain, located at strategic points in the developing world, that would be overseen by the United
Nations World Food Programme. Current emergency grain reserves are controlled nationally and lack international coordination.

In addition, a global intelligence unit should be created to advise when market intervention is needed. Should grain prices be driven into a price bubble again, an international body could act through the futures market - effectively promising to sell grain at low prices in the future. In most cases, this should cause prices to decline before sells are realized, so no actual money need change hands. In the unusual circumstance in which this futures activity would need to be paid for, the international body would have to draw on a 'virtual reserve' - a promise of funds from participating nations ${ }^{6}$. After discussion at the 2008 G8 (Group of Eight) summit of the world's leading industralized nations, such a scheme is now under consideration at high political levels.

At the same time, subsidies for biofuels, which have diverted funds from food and feed production, should be removed. Although biofuels will surely play a part in future energy systems, the billions spent on subsidies would be better invested in $\mathrm{R} \& \mathrm{D}$ for innovative biomass use and other energy innovations. Also required is a scaling up of social programmes, including employment programmes, school feeding, and early childhood nutrition interventions.

The successful resolution of the food crisis should not be measured by the drop of commodity prices to previous levels, but by sufficient food on poor people's plates today and long into the future.

Joachim von Braun is the director general of the International Food Policy Research Institute in Washington DC.

e-mail: j.vonbraun@cgiar.org

1. Hunger on the Rise: Soaring Prices Add 75 Million People to Global Hunger Rolls. Briefing paper (FAO, 2008)

2. von Braun, J. Food and Financial Crises: Implications for Agriculture and the Poor (IFPRI, 2008).

3. Fan, S., Gulati, A. \& Thorat, S. Agric. Econ. 39, 163-170 (2008).

4. Beintema, N. M. \& Stads, G.-J. Measuring Agricultural Research Investments: A Revised Global Picture (IFPRI, 2008),

5. World Development Report 2008: Agriculture for Development (World Bank, 2007)

6. von Braun, J. \& Torero, M. Physical and Virtual Global Food Reserves to Protect the Poor and Prevent Market Failure. IFPRI Policy Brief 4 (IFPRI, 2008). 